\title{
IMPROVE PERFORMANCE THROUGH SATISFACTION AND PSYCHOLOGICAL EMPOWERMENT
}

\author{
Sulistiyani $^{1}$, Roh Prihati ${ }^{2}$ \\ Magister Management of Faculty of Economy and Business \\ University of 17 Agustus 1945 Semarang \\ E-mail:tiyani.sulis24@yahoo.com
}

\begin{abstract}
This study aimed to analyze influence of psychological empowerment, effort and satisfaction on performance. In addition, this study also aims to analyze the influence of mediating variables of satisfaction relationship between psychological empowerment and effort on performance. Population and samples taken from doormat maker who are members of the UD. Anugrah 2017 for about 700 people . Samples taken from 106 maker/supplier.. Data collection's methods used by questionnaires. The analytic technique used is regression analysis with Path Analysis. The results showed that : 1). Psychological empowerment effect positive and significant satisfaction. 2). Effort have an possitive effect and significant satisfaction. 3). satisfaction have an possitive effect and significant on performance. 4). Psychological empowerment have an positive effect and significant on performance. 5). Effort have an positive effect and significant on performance.
\end{abstract}

Keyword : Psychological Empowerment, Effort, Satisfaction, Performance

\section{Introduction}

Individual employee is the main factor to define the successful of organization. How the good employees doing their work will influence significantly to productivity and organizational performance. There have 3 main factor that influencing how the individual on work. These factors are the ability of individuals to do work, the level of effort devoted, and organizational support (Silalahi, 2013).

Human resources is the important factor in organizational, more over in global century which is full of competitive challenging. Human resources saying the employee as the crucial resources and need to have special attention because they are the main factor to achieve organizational goals.

Performance is the result of the work that employee achieved by doing and finish the work which is charged to him. (Sunyoto, 2012). Employee performance influenced by various characteristic of personal or individual. In the era of globalization and competitive, organization need employees with the high good performance. In the same time, employee need the impact of their performance for future main action, so, appraisal should be illustrated of employee performance.

Performance is a real behavior displayed by each employee as a work performance generated in accordance with its role in the company (Rivai and Sagala, 2013). The success of an organization to achieve goals and objectives is largely determined by the performance of managers and employee performance. Manager performance is a measure of how managers effectively carry out tasks and efficiently use resources to achieve organizational goals through 
the implementation of management functions. There are three main factors that affect how individuals work. These factors are the ability of individuals to do work, the level of effort devoted, and organizational support (Silalahi, 2013).

Many factors can affect performance. According to Christen, et all (2006), Djamaludin (2009), Ajzen (2011), Koesmono (2011), Nugroho (2011), Puspokusumo and Cathhleen (2011), Rahmasari (2011), Rohman, et al (2012) and Taurisa and 2011 Ratnawati (2012), factors that can affect performance are psychological empowerment, effort and organizational satisfaction.

In this study there was a gap between the results of previous studies, so this study intends to discuss previous research. The object of this research is UD. Anugrah which is a handicraft business from garment's scrap in Desa Wonoyoso, Pringapus District, Semarang Regency. UD. Anugrah is one of the home industry of making doormats and has 700 maker / supplier. Supplier are expected to be able to supply more doormats, but not all of these supllier are active in making mat, because several supplier take indisciplinary actions, if not supply the mat in the same quantity should be, so this has an impact decrease during the period January - June 2017

\section{Theoretical Review}

\subsection{Psychological Empowerment}

Psychological empowerment is a motivational action for employees to do work as effectively as possible (Gunawan, 2012). Empowerment is putting workers accountable for what they do. Thus, managers learn to stop controlling and workers learn together how to be responsible for their work and make appropriate decisions (Pratiwi, 2012). Empowerment is an employee engagement that really matters. Psychological empowerment is the authority to make decisions in a certain area of operations without having to get the approval of others (Pratiwi, 2012).

Empowering people can be done by moving them from positions that usually only do what is told, into positions that provide opportunities for more responsibility (Fitriah and Sudibya, 2015). Employee empowerment can make employees fully responsible for what they do, this makes managers forced to learn to release the control, while employees are forced to learn to be responsible for their work and make the right decisions.

Empowerment is based on social exchange theory, so this literature interprets power as a function of the dependence and independence of the actors (Gunawan, 2012). The relative power that an actor has over other actors is a product of the amount of dependence that one has on the other. In the motivational sense, power is an intrinsic need from within an individual to have freedom of decision making, or an intrinsic need to feel confident in self-efficacy.

\subsection{Effort}

Effort is an effort made by someone to reach the target (Puspokusumo and Cathleen, 2011). In expectation theory says an employee is motivated to carry out a high level of effort if he believes the effort will lead to a good performance appraisal.

Human resources are the most important factor in an organization because they are the driving factors of the organization's wheels, for this reason an adequate capability is required especially for the employees implementing a policy program. The abilities that a person has are obtained from education, training, and work experience. Highly educated people have different abilities from people with less education, people who have never attended training, and people who have no experience. If an employee has high ability in work, he has more confidence so that it is possible to show different performance from employees with lower ability. 


\subsection{Satisfaction}

Job satisfaction expressed by Luthans (1998) is a positive and pleasant emotional stage of a person resulting from the assessment of a job or work experience. The five models of job satisfaction, proposed by Kreitner \& Kinichi (2005) are; First, the fulfillment of needs, this model explains that satisfaction is determined by the characteristics of a job that allows someone to meet their needs. Secondly, there is a mismatch, this model explains that satisfaction is the result of fulfilled expectations. Thirdly, the achievement of value, this model explains that satisfaction comes from the perception that a job makes it possible to fulfill the important work values of individuals. Fourth equation, this model of satisfaction is a function of how an individual is treated in the workplace. The fifth character / genetic, this model tries to explain some people are satisfied with certain work situations and conditions,

Celluci and De Vries (1978) in Fuad Mas'ud (2004) formulate indicators of job satisfaction in 5 indicators as follows:

1. Satisfaction with salary

2. Satisfaction with promotion

3. Satisfaction with coworkers

4. Satisfaction with supervisors

5. Satisfaction with the work itself

Lund (2003) in his research showed that job satisfaction which is described in salary satisfaction, promotion, supervision and cooperation among workers has a very big influence on improving their performance, but it is highly influenced by a work culture that is conducive for workers to the organization. This will give an overview of their actions, reactions and decisions to their respective work situations.

A person who is highly committed might see himself as a true member of a company, refer to the organization in personal terms, ignore the source of minor dissatisfaction, and see himself as a member of the organization. Conversely, someone who is less committed is more likely to see himself as an outsider, express more dissatisfaction about many things, and not see himself as a long-term member of the organization (Moorhead and Griffin, 2013).

\subsection{The performance}

Performance is the result of quality and quantity of work achieved by an employee in carrying out their duties in accordance with the responsibilities given to him (Mangkunegara, 2009). Another definition of performance is the output produced by the functions or indicators of a job or a profession within a certain time (Wirawan, 2009). According to Sutrisno (2012), performance is the result of work achieved by someone from his work behavior in carrying out work activities. Meanwhile, according to Bangun (2012), performance is the result of work achieved by employees based on job requirements. Also according to Silalahi (2013), performance is the level of achievement of individual work (employees) after trying or working hard or the end result of an activity. Another understanding of performance is the real behavior displayed by each employee as a work performance generated in accordance with its role in the company (Rivai and Sagala, 2013).

Organizations are groups of people who work together in one structure to achieve common goals. There are two parties responsible for achieving organizational goals, objectives and targets, they are the managers and employees, both as individuals and as groups. The manager's job is to set goals and strategies as well as take direction, and coordinate to achieve them. 
International Journal of Economics, Business and Accounting Research (IJEBAR)

Peer Reviewed - International Journal

Vol-4, Issue-1, 2020 (IJEBAR)

E-ISSN: 2614-1280 P-ISSN 2622-4771

https://jurnal.stie-aas.ac.id/index.php/IJEBAR

Managers build work teams that efficiently and effectively achieve organizational goals, objectives, and targets. While employees work according to directions and strategies so that goals and objectives are achieved (Silalahi, 2013).

\subsection{Framework}

Performance is a measure of how employees effectively carry out tasks and efficiently use resources to achieve organizational goals through the implementation of management functions. There are three main factors that affect how individuals work. These factors are the ability of individuals to do work, the level of effort devoted, and organizational support.

Based on the theories that have been put forward and the results of previous studies, the influence of work discipline, career development and job satisfaction on employee performance can be made the following framework:

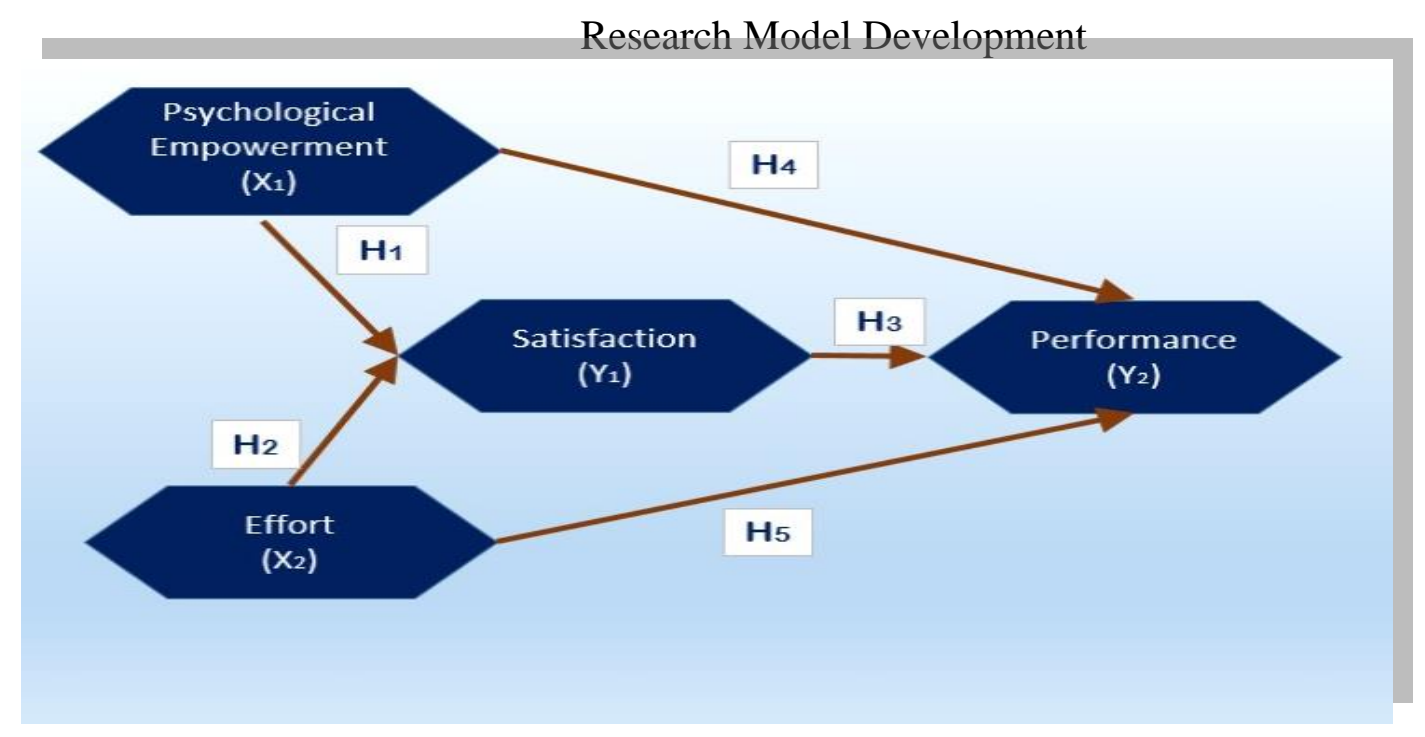

\subsection{Hypothesis}

H1: There is a positive and significant effect between psychological empowerment on satisfaction

According to Cropanzano \& Mitchel (2005), generally a reciprocal exchange relationship will be made when the leader pays attention to an employee, for example with the support given by the leader to his subordinates. Strong relationships ultimately lead to effective work behavior and positive employee attitudes as Commitments. Thus it can be said that Empowerment contributes a sense of effective commitment to the organization through a reciprocal process.

$\mathrm{H} 2$ : There is a positive and significant effect between effort on satisfaction

The next element of work motivation according to George and Jones (2005) is the level of effort (level of effort). The level of effort is related to how hard a person tries to work according to the chosen behavior. Kartika's research results (2010) state that 267 work motivation which is characterized by a high level of effort can increase employee job 
satisfaction. When an employee always strives to utilize time, work skillfully and creatively, make no mistakes at work, and always try to be serious and focused on work, then it is assumed that the employee has high job satisfaction

H3: There is a positive and significant effect between satisfaction on performance

From the research results, it is known that job satisfaction can have a direct influence on employee performance and can have an indirect effect on employee performance through organizational commitment. The results of the study indicate that organizational commitment is a significant intervening variable in the relationship between job satisfaction and performance. Organizational commitment can be a mediator between job satisfaction and performance, because the level of job satisfaction affects the level of commitment of organizational members to the organization and as a consequence, commitment brings to the efforts of organizational members at work and at their performance level (Zhang \& Zheng, 2009).

H4: There is a positive and significant effect between psychological empowerment on performance

There are four dimensions of psychological empowerment variables, meaningfulness, competence, self-determination and impact Spreitzer (1999) concludes that these four dimensions are manifestations of psychological empowerment (p. 1444). the researcher wants to know the effect of psychological empowerment on performance and this is included in Hypothesis 4

H5: There is a positive and significant effect between effort on performance According to Jackson, S. L. (2007). Effort (effort) is an effort issued by employees in carrying out their duties. Good business is influenced by good motivation and high morale. An employee must have a high effort towards his work so as to create a high performance. The effort expended by an employee is influenced by motivation, work ethics, attendance and task design.

\section{Research Method}

\subsection{Definition of Variable Operations}

Variables and operational definitions of variables in this study are:

A. Independent variable is the variable that is the cause / effect of the dependent variable / bound (Umar, 2013). The independent variables in this study consisted of:

1. Psychological Empowerment (X1)

Psychological Empowerment is measured through indicators (Gunawan, 2012):

a. Work is very important

b. Confident of ability to work

c. Confidently carry out the task

d. Mastering skills

e. Can determine their own work

f. Having freedom of work

2. Effort (X2)

Effort is measured through indicators (Puspokusumo and Cathleen, 201):
a. Motivation
b. Work Ethics
c. Presence
d. Task design 
B. Intervening Variables are variables that affect the relationship between independent and dependent variables, but cannot be observed and measured (Umar, 2013). Intervening variables in this study are:

3. Satisfaction (Y1)

C. Bound Variable, the variable whose value is influenced by the independent / independent variable (Umar, 2013). Independent variables in this study are:

4. Performance (Y2)

Performance is measured through indicators (Pratiwi, 2012):
a. High morale
b. Do a good job
c. Can work with other employees
d. Initiative and independent in working
e. Comply with regulations
f. Attention to work
g. Make a harder effort

\subsection{Data Types and Sources}

The type of data used is primary data. Primary data used in this study are employee responses obtained through questionnaires about psychological empowerment, effort, satisfaction, performance.

\subsection{Population and Sample}

The population in this research is the mat supplier who was a member of UD. Anugrah in 2015 about 700 people.

The sample in this research is some of the mat suppliers were a member of UD. Anugerah in 2015 with the Slovin method obtained a sample of 106 people.

\subsection{Method of collecting data}

Data collection methods used were questionnaires. Questionnaire is a data collection technique that is done by giving a set of questions or written statements to respondents to be answered (Sugiyono, 2012).

\subsection{Analysis Techniques}

Path Analysis

The analysis technique in this study is Path Analysis which is a technique to analyze the pattern of relationships between variables with the aim to determine the direct or indirect influence of a set of independent (exogenous) variables on the dependent variable (endogenous) (Riduwan and Kuncoro, 2008: 2).

Sub Structure Equation I:

$$
\mathrm{Y}_{1}=\mathrm{b}_{1} \mathrm{X}_{1}+\mathrm{b}_{2} \mathrm{X}_{2}+e_{1}
$$

Sub Structure Equation II:

\section{Result and Discussion}

\subsection{Results of Multiple Regression Analysis}

Psychological Empowerment and Effort Against Organizational Commitment 
International Journal of Economics, Business and Accounting Research (IJEBAR)

Peer Reviewed - International Journal

Vol-4, Issue-1, 2020 (IJEBAR)

E-ISSN: 2614-1280 P-ISSN 2622-4771

https://jurnal.stie-aas.ac.id/index.php/IJEBAR

\section{COEFFICIENTS}

\begin{tabular}{|c|r|r|r|r|r|}
\hline \multirow{2}{*}{ Model } & \multicolumn{2}{|c|}{$\begin{array}{c}\text { Unstandardized } \\
\text { Coefficient }\end{array}$} & $\begin{array}{l}\text { Standardized } \\
\text { Coefficient }\end{array}$ & \multicolumn{1}{c|}{ t } & \multirow{2}{*}{ Sig. } \\
\cline { 2 - 4 } & \multicolumn{1}{c|}{ B } & Std.Error & \multicolumn{1}{c|}{ Beta } & \\
\hline 1. (Constant) & 0,975 & 0,862 & & 1,132 & 0,26 \\
\hline $\begin{array}{c}\text { Psychologycal } \\
\text { empowerment }\end{array}$ & 0,318 & 0,5 & 0,397 & 6,316 & 0,000 \\
\hline Effort & 0,66 & 0,74 & 0,563 & 8,957 & 0,000 \\
\hline
\end{tabular}

Source: Primary Data Processed, 2017

Based on the results of the regression coefficient, a linear equation can be made between the effects of psychological empowerment and effort on satisfaction as follows:

$\mathrm{Y}_{1}=0,397 \mathrm{X}_{1}+0,563 \mathrm{X}_{2}$

The results of the regression can be interpreted as follows:

a. Psychological empowerment $\left(b_{1}\right)$ has a positive value of 0.397 , meaning that every time there is an increase in psychological empowerment, it will increase organizational satisfaction.

b. Effort $\left(b_{2}\right)$ has a positive value of 0.563 , meaning that every time there is an increase in effort it will increase organizational satisfaction.

Results of the regression Pscyhological empowerment, Effort, and Satisfaction of Supplier Performance

\section{COFFFICIENTS}

\begin{tabular}{|c|c|c|c|c|c|}
\hline \multirow[t]{2}{*}{ Model } & \multicolumn{2}{|c|}{$\begin{array}{c}\text { Unstandardized } \\
\text { Coefficient }\end{array}$} & \multirow{2}{*}{$\begin{array}{c}\text { Standardized } \\
\text { Coefficient }\end{array}$} & \multirow[t]{2}{*}{$\mathrm{t}$} & \multirow[t]{2}{*}{ Sig. } \\
\hline & B & Std.Error & & & \\
\hline 1. (Constant) & 0,008 & 1,338 & & 0,006 & 0,995 \\
\hline $\begin{array}{l}\text { Psychologycal } \\
\text { empowerment }\end{array}$ & 0,203 & 0,91 & 0,167 & 2,224 & 0,028 \\
\hline Effort & 0,351 & 0,152 & 0,197 & 2,315 & 0,023 \\
\hline $\begin{array}{c}\text { Organizational } \\
\text { Satisfaction }\end{array}$ & 0,864 & 0,152 & 0,568 & 5,681 & o \\
\hline
\end{tabular}

a. Dependent Variable : Supplier Performance

Source: Primary Data Processed, 2016

Based on the results of the regression coefficient, it can be made a linear equation between the effects of psychological empowerment, effort, and satisfaction on the performance of supplier as follows:

$\mathrm{Y}_{2}=0,167 \mathrm{X}_{1}+0,197 \mathrm{X}_{2}+0,568 \mathrm{Y}_{1}$

The results of the regression can be interpreted as follows:

a. Psychological empowerment $\left(b_{1}\right)$ has a positive value of 0.167 , meaning that every time there is an increase in psychological empowerment, it will improve the performance of supplier 
International Journal of Economics, Business and Accounting Research (IJEBAR)

Peer Reviewed - International Journal

Vol-4, Issue-1, 2020 (IJEBAR)

E-ISSN: 2614-1280 P-ISSN 2622-4771

https://jurnal.stie-aas.ac.id/index.php/IJEBAR

b. Effort $\left(b_{2}\right)$ has a positive value of 0.197 , meaning that every time there is an increase in effort it will improve the performance of the supplier

c. Satisfaction $\left(b_{3}\right)$ has a positive value of 0.568 , meaning that every time there is an increase in organizational satisfaction it will improve the performance of the supplier

Coefficient of Determination

Psychological Empowerment, Effort, and satisfaction with

Supplier Performance

\section{Model Summary}

\begin{tabular}{|c|c|c|c|c|}
\hline Model & R & R Square & $\begin{array}{c}\text { Adjusted R } \\
\text { Square }\end{array}$ & $\begin{array}{c}\text { Std.Error of } \\
\text { Estimate }\end{array}$ \\
\hline 1 & $0,874^{\mathrm{a}}$ & 0,764 & 0,76 & 1,597 \\
\hline
\end{tabular}

a. Predictors : (Constant), Effort, Psychological Empowerment

Source: Primary Data Processed, 2016

The coefficient of determination can be seen in Adjusted $R$ Square of 0.760. This value can be interpreted that psychological empowerment and effort can explain satisfaction by $76.0 \%$ $(0.760 \times 100 \%)$, while for $24.0 \%(100 \%-76.0 \%)$ satisfaction is explained by variables beyond psychological empowerment and effort.

Model Summary

\begin{tabular}{|c|c|c|c|c|}
\hline Model & R & R Square & $\begin{array}{c}\text { Adjusted R } \\
\text { Square }\end{array}$ & $\begin{array}{c}\text { Std. Error of } \\
\text { Estimate }\end{array}$ \\
\hline 1 & $0,872^{a}$ & 0,76 & 0,753 & 2465 \\
\hline
\end{tabular}

a. Predictors : (Constant), Organizational Commitment, Psychological, Effort

Source: Primary Data Processed, 2016

The coefficient of determination can be seen in Adjusted R Square of 0.753. This value can be interpreted that psychological empowerment, effort, and organizational satisfaction can explain the performance of supplier by $75.3 \%(0.753$ X 100\%), while for $24.7 \%(100 \%-75.3 \%)$ the performance of supplier is explained by variables in beyond psychological empowerment, effort, and organizational satisfaction.

Test - Test Results - F

Psychological and Effort Empowerment of Organizational Satisfaction 
International Journal of Economics, Business and Accounting Research (IJEBAR)

Peer Reviewed - International Journal

Vol-4, Issue-1, 2020 (IJEBAR)

E-ISSN: 2614-1280 P-ISSN 2622-4771

https://jurnal.stie-aas.ac.id/index.php/IJEBAR

ANOVA $^{\text {b }}$

\begin{tabular}{|c|c|c|c|c|c|}
\hline Model & $\begin{array}{c}\text { Sum of } \\
\text { Squares }\end{array}$ & df & Mean Square & F & Sig. \\
\hline 1. Regression & 851,241 & 2 & 425,621 & 168,817 & $0,000^{\text {a }}$ \\
\hline Residual & 262,796 & 103 & 2,551 & & \\
\hline Total & 1114,038 & 105 & & & \\
\hline
\end{tabular}

a. Predictors : (Constant), Effort, Psychological empowerment

b. Dependent Variable : Organizational satisfaction

The result of the Test- F was 166,817 with sig.0,000. Sig value obtained smaller $(<) \alpha=$ 0.05 , so the regression model can be used to predict variables independent and shows that the regression model used is declared fit or good.

The result of the F-test was 166,817 with sig.0,000. Sig value obtained smaller $(<) \alpha=0.05$, so the regression model can be used to predict variables independent and shows that the regression model used is declared fit or good

\section{Test Result $-\mathrm{F}$}

Psychological Empowerment, Effort and Satisfaction on Supplier Performance

ANOVA $^{\text {b }}$

\begin{tabular}{|c|c|c|c|c|c|}
\hline Model & $\begin{array}{c}\text { Sum of } \\
\text { Squares }\end{array}$ & $\mathrm{df}$ & Mean Square & $\mathrm{F}$ & Sig. \\
\hline 1. Regression & 1958,792 & 3 & 652,931 & 107,444 & $0,000^{\mathrm{a}}$ \\
\hline Residual & 619,85 & 102 & 6,07 & & \\
\hline Total & 2578,642 & 105 & & & \\
\hline
\end{tabular}

a. Predictors : (Constant), Effort, Psychological empowerment

b. Dependent Variable : Organizational satisfaction

Source: Primary Data Processed, 2016

The Test-F results were 107.444 with sig.0,000. Sig value obtained smaller $(<) \alpha=0.05$, so, the regression model can be used to predict the independent variables and show that the regression model used is declared fit or good

Test $-\mathrm{t}$

Psychological Empowerment and Effort to Satisfaction 
International Journal of Economics, Business and Accounting Research (IJEBAR)

Peer Reviewed - International Journal

Vol-4, Issue-1, 2020 (IJEBAR)

E-ISSN: 2614-1280 P-ISSN 2622-4771

https://jurnal.stie-aas.ac.id/index.php/IJEBAR

COEFFICIENTS ${ }^{a}$

\begin{tabular}{|c|c|c|}
\hline Model & $\mathrm{t}$ & Sig. \\
\hline 1. (Constant) & 1,132 & 0,26 \\
\hline $\begin{array}{l}\text { Psychologycal } \\
\text { empowerment }\end{array}$ & 6,316 & 0,000 \\
\hline Effort & 8,957 & 0,000 \\
\hline
\end{tabular}

a. Dependent Variable : Organizational satisfaction

Source : Data Primary Processed, 2016.

Based on the results of test uji- $t$, the following tests can be made:

a. Test-t results of psychological empowerment of satisfaction amounted to 6.316 with sig.0,000.

Sig value obtained in accordance with the provisions of acceptance of the hypothesis that is sig. $\leq \alpha=0.05$, so accepting the hypothesis stated is a positive and significant influence between psychological empowerment on organizational satisfaction.

b. The results of the uji $-\mathrm{t}$ for satisfaction of 8,957 with sig.0,000. Sig value obtained in accordance with the provisions of acceptance of the hypothesis that is sig. $\leq \alpha=0.05$, thus accepting the hypothesis that there is a positive and significant effect between effort on satisfaction.

Test $-\mathbf{t}$

Psychological Empowerment, Effort and Satisfaction to Supplier Performance COEFFICIENTS $^{\text {a }}$

\begin{tabular}{|c|c|c|}
\hline Model & $\mathrm{t}$ & Sig. \\
\hline 1. (Constant) & 0,006 & 0,995 \\
\hline $\begin{array}{l}\text { Psychologycal } \\
\text { empowerment }\end{array}$ & 2,224 & 0,028 \\
\hline Effort & 2,315 & 0,023 \\
\hline Organizational satisfaction & 5,681 & 0,000 \\
\hline
\end{tabular}

a. Dependent Variable : Supplier Performance

Source: Primary Data Processed, 2016

Based on the results of the uji $-\mathrm{t}$, the following tests can be made:

a. Test- $t$ results of psychological empowerment on the performance of craftsmen amounted to 2.224 with sig.0.028. Sig value obtained in accordance with the provisions of acceptance of the hypothesis that is sig. $\leq \alpha=0.05$, thus accepting the hypothesis that states there is a positive and significant influence between psychological empowerment on performance.

b. T-test results on the performance of supplier of 2,315 with sig.0,023. Sig value obtained in accordance with the provisions of acceptance of the hypothesis that is sig. $\leq \alpha=0.05$, so accepting the hypothesis stating there is a positive and significant effect of effort on performance. 
c. T-test results of satisfaction with the performance of craftsmen amounted to 5.681 with sig.0,000. Sig value obtained in accordance with the provisions of acceptance of the hypothesis that is sig. $\leq \alpha=0.05$, thus accepting the hypothesis that there is a positive and significant effect between satisfaction on performance.

\subsection{Discussion}

1. Psychological empowerment of doormat supplier at UD Anugerah needs to be improved, like by giving freedom to carry out work so supplier psychologically feel more comfortable because they can do their own planning in carrying out work processes such as designing shapes or patterns for mats to be produced. This will further support the performance improvement of supplier.

2. Effort's shown by the doormat supplier at UD Anugerah also needs to be improved, like the UD Anugerah party needs to make a design that is more easily understood by the supplier, such as compiled in the form of a book that are easily read and understood by supplier who on average have junior high school education. It also needs to be given direct instruction and guidance so that the supplier in carrying out the production process can produce quality and quantity in accordance with the wishes of UD Anugerah.

3. The satisfaction of the craftsmen still needs to be improved, especially the desire of the supplier to remain willing to work at UD Anugerah in long time, which can be done by giving rewards like bonuses when they are able to reach production targets, and also increase capital for the supplier so that the they are become more feel comfortable working at UD Anugerah and become a stimulus to improve their performance in producing doormat products.

4. For other researchers, the results of this study can be used as data to conduct similar research on other factors that affect performance such as work motivation, organizational culture and so on in other agencies in Regional Semarang.

\section{Conclusion}

From the description above can be drawn conclusion : (a) Psychological empowerment has a positive and significant effect on satisfaction. (b) Effort has a positive and significant effect on organizational satisfaction. (c) Satisfaction has a positive and significant effect on performance. (d) Psychological empowerment has a positive and significant effect on performance. (e) Effort has a positive and significant effect on performance.

\section{Reference}

Bangun, Wilson. 2012. Manajemen Sumber Daya Manusia. Jakarta. Erlangga.

Cellucci, Anthony J, \& David L. De Vries (1978), Measuring Managerial Satisfaction : A Manual for the MJSQ, Technical Report II (Center for Creative Leadership).

Cropanzano, R., \& Mitchell, M. S. (2005). Social exchange theory: An interdisciplinary review. Journal of management, 31(6), 874-900.

Djamaludin, Musa. 2009. "Pengaruh Komitmen Organisasional, Pengembangan Karier, Motivasi Kerja dan Karekeristik Individual terhadap Kepuasan Kerja dan Kinerja Pegawai Pemerintah Kabupaten Halmahera Timur”. Jurnal Ilmu Ekonomi dan Manajemen. Vol. 5. No. 2. Januari 2009. Hal. 1 - 80. Surabaya. Universitas 17 Agustus 1945.

Fitriah dan I Gede Adnyana Sudibya. 2015. "Pengaruh Pemberdayaan Karyawan Dan Kepuasan Kerja Terhadap Komitmen Organisasional Sekretariat Perusahaan Daerah Pasar Kota 
Denpasar”. E-Jurnal Manajemen Unud. Vol. 4. No. 11. 2015. Hal. 3478 - 3507. Bali. Universitas Udayana Bali.

George, J. M., Jones, G. R., \& Sharbrough, W. C. (2005). Understanding and managing organizational behavior. Upper Saddle River, NJ: Pearson Prentice Hall.

Ghozali, Imam. 2009. Aplikasi Analisis Multivariate Dengan Program SPSS. Cetakan Keempat. Semarang.Badan Penerbit Universitas Diponegoro.

Griffin, Moorhead. 2013. Perilaku Organisasi ( manajemen sumber daya manusia dan organisasi). Edisi 9. Salemba empat.

Gunawan, Andreas Wahyu dan Okta Viyanita. 2012. "Pemberdayaan Psikologi : Hubungannya Dengan Kepuasan Kerja dan Komitmen Afektif". Media Riset Bisnis \& Manajemen. Vol. 12. No. 1. April 2012. Hal. 1-17. Jakarta. Universitas Trisakti.

Jackson, S. L. (2007). Program effectiveness of job readiness training: An analysis and evaluation of selected programs in St. Louis, Missouri. Capella University.

Koesmono, Teman. 2011. "Pengaruh Budaya Organisasi dan Kepemimpinan terhadap Kinerja Melalui Variabel Mediasi Komitmen Organisasional Karyawan Perusahaan Swasta di Surabaya Timur". Jurnal Mitra Ekonomi dan Manajemen Bisnis. Vol.2. No. 2. Oktober 2011. Hal. 155-171. Surabaya. Universitas Khatolik Widya Mandala.

Kreitner, Robert dan Angelo Kinicki. 2014. Perilaku Organisasi. Edisi 9. Buku 1. Jakarta. Salemba Empat.

Kreitner, R., Kinicki, A., \& Buelens, M. (2002). Organizational behaviour. London, UK: McGraw Hill.

Luthans, F. (1998) Organizational Behavior. 8th Edition, Irwin McGraw-Hill, Boston.

Lund, D. (2003). Organizational culture and job satisfaction. Journal of Business \& Industrial Marketing, 18, 219-236. doi:10.1108/0885862031047313

Madhuri, Kumari, Prabhat Srivastava and Preeti Srivastava. 2014. "The Effect Of Organizational Commitment, And Job Satisfaction, On Employee's Job Performance.”. International Journal of Art \& Humanity Science (IJAHS). Volume 1 Issue 2, (Sep-Oct 2014), PP. 20 23. Global Institute of Information \& Technology. Greater Noida, UP. India

Mangkunegara, Anwar Prabu. 2009. Manajemen Sumber Daya Manusia. Cetakan Kesembilan. Bandung. PT. Remaja Rosdakarya.

Moorhead, Gregory dan Ricky W. Griffin. 2013. Perilaku Organisasi : Manajemen Sumber Daya Manusia dan Organisasi. Edisi 9. Jakarta. Salemba Empat.

Murty, Windy Aprila dan Gunasti Hudiwinarsih. 2012. "Pengaruh Kompensasi, Motivasi Dan Komitmen Organisaisonal Terhadap Kinerja Karyawan Bagian Akuntansi (Studi Kasus Pada Perusahaan Manufaktur di Surabaya”. Journal of The Indonesian Accounting Review. Volume 2. No. 2. Juli 2012. Hal. 215 - 228. Surabaya. STIE Perbanas Surabaya.

Noor, Zainul Arifin. 2012. "Pengaruh Budaya Organisasi, Komitmen Organisasi dan Motivasi Kerja terhadap Kepuasan Kerja dan Kinerja Karyawan”. Jurnal Ekonomi dan Keuangan. Volume 16. Nomor 4. Desember 2012: Hal. 473 - 486. Kalimantan Selatan. Universitas Achmad Yani Banjarmasin.

Nugroho, Dwiyekti Agung. 2011. "Pengaruh Budaya Organisasi dan Gaya Kepemimpinan Transformasional terhadap Komitmen Organisasi dan Kinerja Pegawai (Studi Pada Pusat Pengembangan dan Pemberdayaan Pendidik dan Tenaga Kependidikan/ Vocational Education Development Center Malang”. Jurnal Manajemen Bisnis. Vol. 1. No. 2. Oktober 2011. Hal. 167 - 176. Malang. 
International Journal of Economics, Business and Accounting Research (IJEBAR)

Peer Reviewed - International Journal

Vol-4, Issue-1, 2020 (IJEBAR)

E-ISSN: 2614-1280 P-ISSN 2622-4771

https://jurnal.stie-aas.ac.id/index.php/IJEBAR

Nursyamsi, Idayanti. 2012. "Pengaruh Kepemimpinan, Pemberdayaan, dan Stres Kerja Terhadap Komitmen Organisasional serta dampaknya terhadap Kinerja Dosen". Conference in Business, Accounting, and Management (CBAM). Tgl 6-7 Desember 2012. Hal. 1 - 16. Semarang. Universitas Islam Sultan Agung (Unissula) Semarang

Pratiwi, Putri. 2012. "Pengaruh Budaya Organisasi dan Pemberdayaan terhadap Komitmen Organisasional dalam Meningkatkan Kinerja”. Aset. Maret 2012. Hal. 41-52. Semarang. Universitas Dian Nuswantoro (UDINUS) Semarang.

Purnama, Chamdan. 2013. "Influence Analysis of Organizational Culture, Organizational Commitment and Job Satisfaction on Organizational Citizenship Behavior (OCB) Toward Improved Organizational Performance". International Journal of Business, Humanities and Technology. Vol. 3 No. 5; May 2013. Mojokerto: Sekolah Tinggi Ilmu Ekonomi Al-Anwar Mojokerto. Jawa Timur. Indonesia.

Puspokusumo, Aryanti Wardaya dan Leonny Cathleen. 2011. "Analisis Pengaruh Ability, Effort Dan Support Terhadap Kinerja Karyawan Toko Buku Gramedia Cabang Plaza Semanggi”. Jurnal Binus Business Review. Vol. 2 No. 2. November 2011. Hal. 738-750. Jakarta. BINUS University.

Rahmasari, Lisda. 2011. "Peningkatan Motivasi Melalui Pemberdayaan Psikologis Dan Dampaknya Terhadap Kinerja Karyawan”. Majalah Ilmiah INFORMATiKA. Vol. 2 No.1. Januari 2011. Hal. 57 - 67. Semarang. Universitas AKI.

Riduwan dan Engkos Achmad Kuncoro. 2008. Cara Menggunakan Dan Memakai Analisis Jalur (Path Analysis). Cetakan Kedua. Bandung. Alfabeta.

Rivai, Veithzal dan Ella Jauvani Sagala. 2013. Manajemen Sumber Daya Manusia untuk Perusahaan : Dari Teori ke Praktik. Edisi Kedua. Cetakan Kelima. Jakarta. PT. Rajagrafindo Persada.

Rohman, Fatchur, Armanu dan Novita Mandayanti. 2012. "Pengaruh Pemberdayaan Psikologis dan Komtmen Afektif terhadap Kepuasan Kerja dan Kinerja Pegawai (Studi pada Dinas Tata Kota dan Pengawasan Bangunan Kota Mataram)”. Jurnal Aplikasi Manajemen. Vol. 10. No. 1. Maret 2012. Hal. 152 - 160. Malang. Universitas Brawijaya Malang.

Sangadji, Etta Mamang. 2009. "Pengaruh Budaya Organisasi dan Komitmen Organisasional Pimpinan terhadap Kepuasan Kerja da n Dampaknya pada Kinerja”. Jurnal Paedagogia. Jilid 12. Nomor 1. Februari 2009. Halaman 52 - 65. Jawa Timur. STKIP PGRI Pasuruan.

Sarwono, Jonathan. 2007. Analisis Jalur untuk Riset Bisnis dengan SPSS. Edisi I. Yogyakarta. Andi.

Silalahi, Ulber. 2013. Asas-Asas Manajemen. Cetakan Kedua. Bandung. PT. Refika Aditama.

Siregar, Syofian. 2013. Metode Penelitian Kuantitatif : Dilengkapi Perhitungan Manual \& SPSS. Edisi Pertama. Cetakan ke 1. Jakarta. Kencana Prenada Media Group.

Sugiyono. 2012. Metode Penelitian Bisnis. Cetakan Ke-16. Bandung. Alfabeta.

Sunarsih, Nenah, Sri Hartoyo dan Sukismo Dirdjosuparto. 2011. ”Pengaruh Budaya Organisasi dan Kepuasan Kerja terhadap Komitmen Organisasi Staf Administrasi Universitas Terbuka (UT)”. Forum Pascasarjana. Vol. 34. No. 2. April 2011. Hal. 125 - 133. Bogor: Institut Pertanian Bogor.

Sunyoto, Danang. 2012. Teori, Kuesioner, Dan Analisa Data Sumber Daya Manusia. Yogyakarta. Center for Academic Publishing Service (CAPS).

Sutrisno, Edy. 2012. Manajemen Sumber Daya Manusia. Edisi 1. Cetakan Keempat. Yakarta. Prenada Media Group. 
International Journal of Economics, Business and Accounting Research (IJEBAR)

Peer Reviewed - International Journal

Vol-4, Issue-1, 2020 (IJEBAR)

E-ISSN: 2614-1280 P-ISSN 2622-4771

https://jurnal.stie-aas.ac.id/index.php/IJEBAR

Spreitzer, G. M., De Janasz, S. C., \& Quinn, R. E. (1999). Empowered to lead: The role of psychological empowerment in leadership. Journal of Organizational Behavior: The International Journal of Industrial, Occupational and Organizational Psychology and Behavior, 20(4), 511-526.

Syauta, Jack Henry. 2012. "The Influence of Organizational Culture, Organizational Commitment to Job Satisfaction and Employee Performance (Study at Municipal Waterworks of Jayapura, Papua Indonesia)". International Journal of Business and Management Invention. Volume 1Issue 1 December. 2012. PP.69-76. Papua: Cendrawasih University, Jayapura, Papua, Indonesia.

Taurisa, Chaterina Melina dan Intan Ratnawati. 2012. “Analisis Pengaruh Budaya Organisasi dan Kepuasan Kerja terhadap Komitmen Organisasional dalam Meningkatkan Kinerja Karyawan (Studi pada PT. Sido Muncul Kaligawe Semarang)". Jurnal Bisnis dan Ekonomi (JBE). Vol. 19. No. 2. September 2012. Hal. 170 - 187. Semarang. UNDIP.

Umar, Husein. 2013. Metode Penelitian untuk Skripsi dan Tesis Bisnis. Edisi Kedua. Cetakan Keduabelas. Jakarta. PT. Raja Grafindo Persada.

Wirawan. 2009. Evaluasi Kinerja Sumber Daya Manusia. Teori, Aplikasi, dan Penelitian. Jakarta. Salemba Empat.

Zhang, J., \& Zheng, W. (2009). How does satisfaction translate into performance? An examination of commitment and cultural values. Human Resource Development Quarterly, 20(3), 331-351. 